How to cite: Szatmari, A.C., Tudose, T., Horvath, Cs. (2021) Synoptic and Mesoscale Conditions Generating High Amounts of Precipitation in June 2020, In Romania. 2021 "Air and Water - Components of the Environment" Conference Proceedings, Cluj-Napoca, Romania, p. 43-60, DOI: 10.24193/AWC2021_05.

\title{
SYNOPTIC AND MESOSCALE CONDITIONS GENERATING HIGH AMOUNTS OF PRECIPITATION IN JUNE 2020, IN ROMANIA
}

\author{
Alexandru Cristian SZATMARI , Traian TUDOSE ${ }^{1}$, Csaba HORVATH ${ }^{1}$ \\ DOI: 10.24193/AWC2021_05
}

\begin{abstract}
The first part of the study analyzes the precipitations recorded in June over the 1961-2020 period for 22 climatological weather stations over different regions of Romania in order to determine if precipitations in June 2020 were higher than those recorded before 2020. For this, 5 precipitation indices have been used: number of heavy and very heavy precipitation days, 24-, 48- and 72-hours precipitation amounts. The second part is dedicated to precipitations recorded in June 2020, registered at 157 weather stations from Romania, divided in historical regions; it analyzes the number of heavy and very heavy precipitation days, synoptic and mesoscale conditions from different periods of time using the specific methods of investigation (charts of sea level pressure, geopotential height, temperature and humidity, atmospheric soundings, different stability indices, vertical wind shear, infrared and visible satellite images and radar images of convective storms). The main findings are: precipitations recorded in June 2020 at 22 climatological weather stations did not exceed the absolute maximum precipitation recorded between 1961-2019, and precipitations recorded in 24, 48 and 72 hours were higher only at 2 or 3 weather stations; the number of heavy and very heavy precipitation days recorded in June 2020 were higher in the Carpathians, the North and Center, and the West regions of Romania; synoptic conditions were determined by low values of atmospheric pressure at the surface and/or by the atmospheric depressions, while in the middle troposphere, an atmospheric trough or a cut-off low was present; mesoscale conditions presented low or medium values of Convective Available Potential Energy, negative values of Lifted Index, and weak or medium wind shear in the 0-3 km layer.
\end{abstract}

Keywords: June 2020, precipitation, synoptic, mesoscale, Romania

\section{INTRODUCTION}

The physical processes that are generated in the lower troposphere determine the genesis of many meteorological phenomena, including precipitations. Through their spatial and temporal occurrence, precipitations represent a real interest for economy and environment in the context of increasing their amplitude and manifestation, against the background of the global warming. The special IPCC 2018 Report stipulates, among other things, that ,An average warming of $1.5^{\circ} \mathrm{C}$ across the whole globe raises the risk of heatwaves and heavy rainfall events, amongst many other potential impacts" (IPCC 2018, p.282). Babeş-Bolyai University, Faculty of Geography, Cluj-Napoca, Romania,
alexszatmari1995@yahoo.com,ttraiant@gmail.com, hcsaba@gmail.com 
As Romania lies in the south-eastern part of Europe, its climate is influenced by the cyclonic and anticyclonic activity as well as the polar and tropical air masses advected. On the other hand, the presence and the shape of The Carpathians Range, induces spatial differences in the precipitations recorded. As a consequence, the annual precipitation amount registered in lowlands decreases from the west part of the country $(600 \mathrm{~mm})$ to the south-east (less than $300 \mathrm{~mm}$ in the Danube Delta), and increases with height, on the lee slopes of the mountains (over $1200 \mathrm{~mm}$ ) (Sandu et al, 2008). Seasonally, the highest amount of precipitation in the most part of the country is recorded in summer (over $200 \mathrm{~mm}$ ), and only in the south-east of Romania is less than $110 \mathrm{~mm}$, while June is considered to be the wettest month of the year (Sandu et al, 2008). June's average amount of precipitation for 1961-2019 period varies depending on the region: it grows from less than $55 \mathrm{~mm}$ in Dobrudja, to 65 $91 \mathrm{~mm}$ in Moldavia and south of Romania, to 80-98 $\mathrm{mm}$ in Transylvania, and 84$103 \mathrm{~mm}$ in the west part of the country, while The Carpathians register often more than $100 \mathrm{~mm}$ (Table 1).

Another feature of precipitations recorded in June is their genesis: as diurnal heating is increasing during the summer months, precipitations are generated by thermal or dynamic convection, that can lead to high amount of rainfall in short period of time, and flashfloods on small river basins. As rainfalls are influenced by a large number of factors, like their genesis, physical and geographical features of the terrain etc., most of the studies conducted use different indices to determine the frequency, duration and intensity of extreme precipitations events to different time period (daily, monthly, yearly etc.) and scale (local, regional). Among the studies regarding precipitations recorded in June over the entire Romania and their characteristics, Dragota, 2006, presents a complete profile, including their intensity, while Polifronie, 2014, writes that precipitations recorded in June, 2014 were in the top 4 from the last 50 years. At regional scale of Romania, studies regarding precipitations recorded in June, for different periods of time, were analyzed by Băcescu at al, 2012/2013, for City of Râmnicu Vâlcea, Covaci and Dragomir, 2016, for precipitations registered in Moldavia; features of convective systems generating precipitations and other meteorological phenomena were studied by Pasat and Vasilica, 2016, for the region of Moldavia, Stăncescu and Reckerth, 2016, for Cuci Village - Mureş County, Transylvania, Balga, 2016, for supercell storms from North-Western Romania.

We have chosen to analyze the precipitations recorded in June, 2020, in order to show that, in the context on global warming, events of heavy rainfall (singular or cumulated) tend to increase, leading to negative effects (floods, flash-floods, mudslides, etc.). As atmosphere is becoming more instable in the early summer due to warm and humid air advection and frontal activity, rainfall is getting increasingly heavy as the present study tries to reveal.

Regarding the differences between synoptic scale and mesoscale, synoptic scale refers to the weather systems that have horizontal length of at least $1000 \mathrm{Km}$ and vertical height of $10 \mathrm{Km}$ (https://glossary.ametsoc.org/wiki/Cyclonic_scale), while 
mesoscale refers to weather systems of $5-500 \mathrm{Km}$ lengths, and a lifecycle of one day (Ligda, 1951).

The purpose of the present study is to identify synoptic and mesoscale conditions that generated high amounts of precipitation in June 2020, in Romania. For this, the study was divided into two parts: the first one analyses the precipitations fallen in June for a period 60 years (1961-2020), using 22 climatological weather stations all over the country; the second part studies precipitations recorded in June 2020, using data from 157 weather stations, as well as the synoptic and mesoscale conditions.

At the national level, the maximum discharges in large river catchments are generally registered during the spring time when the precipitation amounts are cumulating with the melting snow discharge. In small catchments, the biggest discharge values and flash floods are registered in the summer, corresponding to the period with high intensity precipitation. This was true also for 2020 , when in the analyzed month at the national level we registered 68 yellow, 51 orange, and 32 red hydrological alerts. Regionally, the highest number of alerts registered in Moldova, followed by Transylvania and the Mountain region.

Analyzing the hydrological warnings by numbers issued by the Somes-Tisa Water Basin Administration in June, there were 396 warnings regarding the overflow of the caution level, 112 overflowing the inundation level and in 9 cases the flood danger level was exceeded. The highest number of warnings were issued between June $21-24$, exceeding $63 \%$ of the total warnings issued in the entire month. This interval can also be identified between the high precipitation periods which were identified in Maramureş, Transylvania and the Mountain region.

\section{DATA AND METHODS}

\subsection{Data used}

The climatological analyses of precipitations registered in June from 1961 to 2020 , for 22 climatological weather stations was used in order to determine the deviation of precipitations fallen in June 2020 over the 1961-2019 period, as well as some precipitation indices. For this, daily datasets of precipitations were freely downloaded from http://data.gov.ro/dataset (for 1961-2016 period), and from http://www.meteomanz.com (for 2017-2020 period), with no more than 5\% of missing data (WMO, 2018). For the analyze of precipitations recorded in June, 2020, data from the 157 weather stations all over the Romania was used, downloaded from http://www.meteomanz.com.

Synoptic analyze was performed using synoptic weather charts at sea level pressure (SLP), geopotential height, temperature and humidity of 925, 850, 700 and $500 \mathrm{hPa}$ accessed from http://www.wetter3.de/archiv_gfs_dt.html, and https://meteologix.com/ro/reanalysis. For the mesoscale analyze, we used atmospheric soundings from Bucharest, Cluj-Napoca, and Szeged (http://weather.uwyo.edu/upperair/sounding.html) in order to determine different stability indices (Convective Available Potential Energy - CAPE, Lifted Index - LI), vertical wind shear in the $0-3 \mathrm{~km}$ layer, humidity in the lower troposphere, infrared 
(IR), visible (VIS) satellite images, and radar images of convective storms (http://eumetrain.org/ePort_MapViewer/index.html, https://www.estofex.org/ modelmaps/browse_gfs.php), for June 2020. As daytime heating and humidity near the surface plays an important role in convective storms development, charts of temperature, dewpoint and accumulated precipitation up to $24 \mathrm{hrs}$. were also used.

As the geographical features of the terrain plays an important role in spatial distribution of precipitations, the study was performed over the historical regions of Romania: Moldavia, Dobrudja, Muntenia and Oltenia, Banat and Crişana, Maramureş and Transylvania, and The Carpathians (Fig. 1).

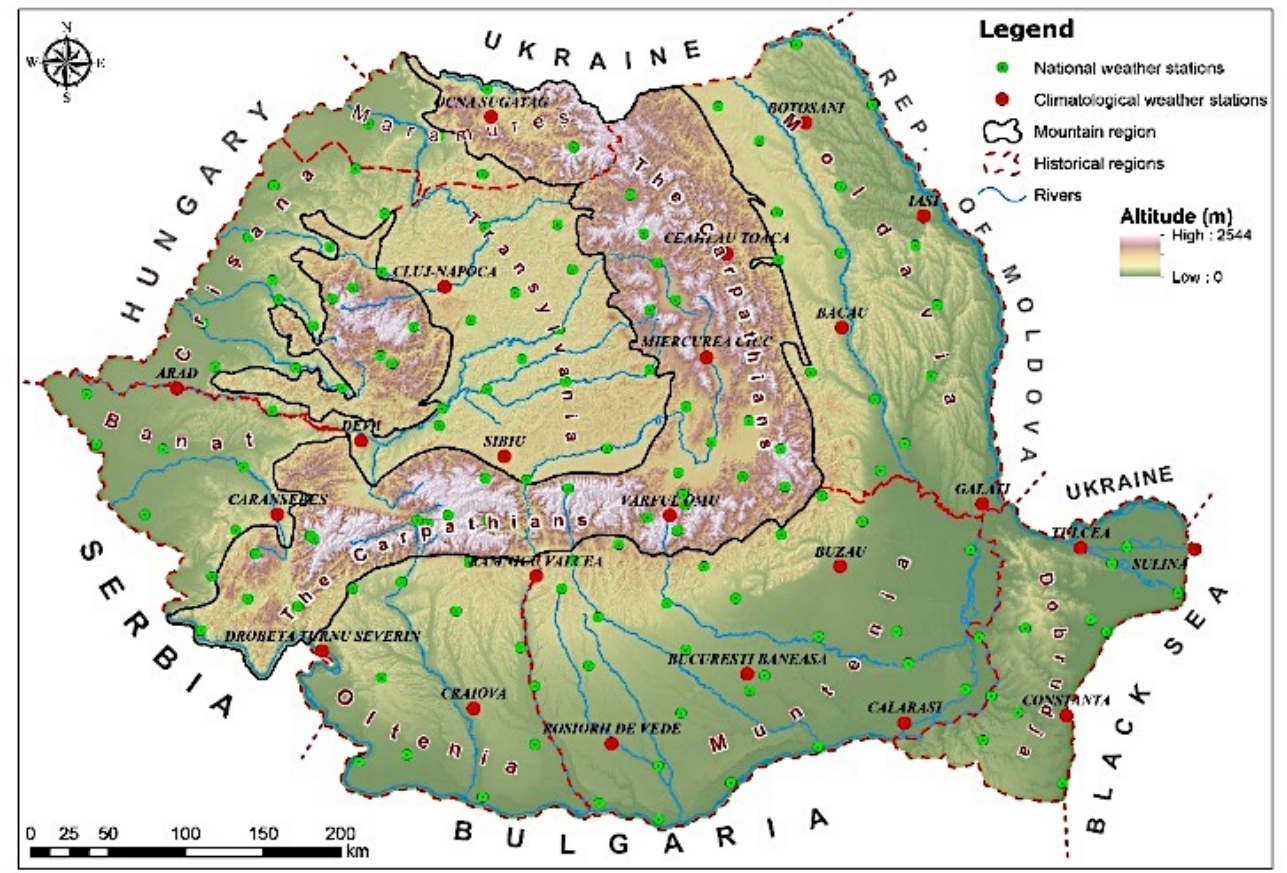

Fig. 1. Spatial distribution of weather stations within the regions used in the study

\subsection{Methods}

For the 22 climatological weather stations, daily precipitation data for the 19612020 period were used in order to determine some precipitation indices. Regarding the types of indices used, some were developed for global scale (e.g., Alexander et al., 2006), mid-scale (e.g., Klein Tank and Können, 2003), or country scale. For the purpose of our study, the following indices have been used: maximum 24-, 48-, and 72-hours precipitation amount, maximum number of heavy precipitation days $(\mathrm{R} \geq$ $10 \mathrm{~mm})$, and very heavy precipitation days $(\mathrm{R} \geq 20 \mathrm{~mm})$ (https://www.ecad.eu/documents/ETCCDMIndicesComparison.pdf).

As only 22 climatological weather stations were not enough to emphasize the extent of events, number of heavy precipitation days and very heavy precipitation days were calculated for June 2020, using data from 157 weather stations from Romania. 
Regarding the synoptic analyze, in order to determine the atmospheric circulation type that generated high precipitations, HYSPLIT model was employed (Draxler and Rolph, 2012). Using a simple air parcel 48-hour backward trajectory option we could identify the direction of the influx and the origin of the air masses in the studied area at different height levels.

\section{RESULTS AND DISCUSSIONS}

\subsection{Synoptic conditions in June, 2020}

Until the $4^{\text {th }}$ of June, over the south-eastern part of Europe, a geopotential trough at the level of $500 \mathrm{hPa}$ was present and gradually weakened as another geopotential trough was forming in the west part of the continent, moving eastward; at the same time, a cut-off low with a geopotential height of 552 damgp was present over the northern part of Romania.

In the next period, a south-western air circulation installed over Romania, generating an advection of hot and humid air from the Mediterranean basin and a rise of temperatures at $850 \mathrm{hPa}$ geopotential height up to $15^{\circ} \mathrm{C}$. Between the $7^{\text {th }}$ and the $9^{\text {th }}$ of June, a geopotential trough formed over the territory of Romania, so the temperatures at $850 \mathrm{hPa}$ level dropped below $15^{\circ} \mathrm{C}$ in the western half of the country (Fig. 2).
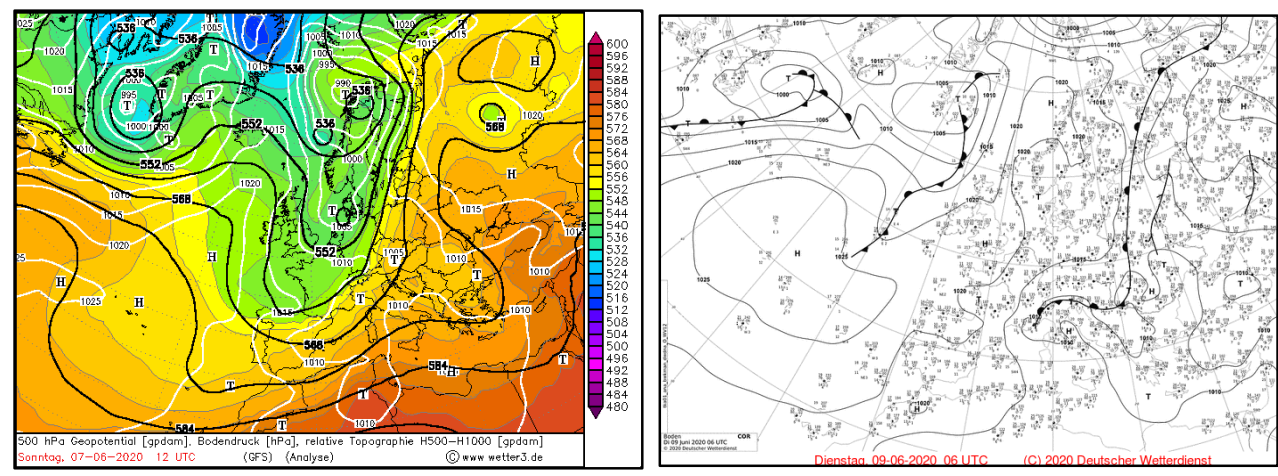

Figure 2. Geopotential height at 500 hPa, Thickness 500-1000 hPa (gpdam), and Sea Level Pressure (hPa) on June, 7, 2020,12 UTC (left), Sea Level Pressure and associated atmospheric fronts (hPa) on June 9, 2020, 06 UTC (right)

(source: http://www1.wetter3.de/archiv)

Beginning with $10^{\text {th }}$ of June, a geopotential trough developed above the southern half of Europe, within a series of rotating cut-off lows (Fig. 3). It must be mentioned that after the $20^{\text {th }}$ of June, the cut-off lows over south-eastern Europe weakened and from June, 26, to the end of the month, the air circulation became mostly western and the geopotential height increased. As a result, from June $10^{\text {th }}$ to June $27^{\text {th }}$, a series of cutoff lows structures were positioned mainly above the south, south-east and eastern part of Romania and the temperatures at $850 \mathrm{hPa}$ geopotential level dropped to $10-12^{\circ} \mathrm{C}$.

During the first 2 days of June 2020, the north-west part of Europe was under the influence of the Scandinavian Anticyclone, while the south-east part of the continent 
was affected by a cyclone situated in the northern part of the Black Sea. As a consequence of this atmospheric situation, between $2^{\text {nd }}$ and $3^{\text {rd }}$ of June, the east and north part of Romania were affected by the activity of a cyclone, moving from the north part of the Black Sea. Between the $3^{\text {rd }}$ of June until the $10^{\text {th }}$, as the Scandinavian Anticyclone moved eastward, a more intense cyclonic activity was developed over the central part of Europe. On the $6^{\text {th }}$ of June, Romania was affected by a cold frontal passage related to an Atlantic depression centered in the Scandinavian Peninsula, and, from June 8 to 9 , another frontal activity was recorded in the west half of the country (Fig. 2).

Between the $10^{\text {th }}$ and the $20^{\text {th }}$ of June, a new anticyclone developed over the Scandinavian Peninsula, while in the south-eastern parts of Europe, SLP was close to $1010 \mathrm{hPa}$ and a series of retrograde depressions were present over the east part of Romania (Fig. 3). From $20^{\text {th }}$ to $25^{\text {th }}$ of June, Azore's ridge situated in the west part of Europe began to move eastward, generating a blocking circulation pattern in the central and eastern part of the continent, therefore, between $24^{\text {th }}$ and $27^{\text {th }}$ of June, SLP in Romania reached values over $1020 \mathrm{hPa}$. After the $25^{\text {th }}$ of June, a mobile anticyclone had separated from the Azore's ridge and moved to the eastern part of the continent in the same time with a cold atmospheric front that belonged to the Icelandic Cyclone and affected the south-eastern part of the continent. The decrease of the SLP over Romania began on the $28^{\text {th }}$ of June, and a frontal activity was recorded.
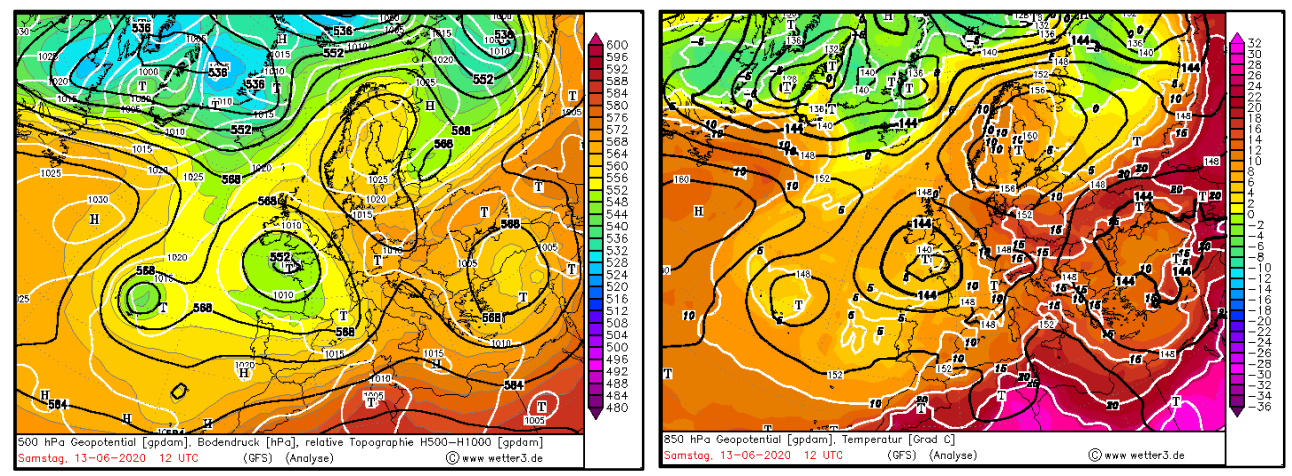

Figure 3. Geopotential height at 500 hPa, Thickness 500-1000 hPa (gpdam), and Sea Level Pressure (hPa)(left), Geopotential height (gpdam) and Temperature $\left({ }^{\circ} \mathrm{C}\right)$ at 850 hPa on June 13, 2020, 12 UTC (right) (source: http://www1.wetter3.de/archiv)

The amounts of precipitation registered in June 2020 were between $2.8 \mathrm{~mm}$ at Sulina (Danube Delta) and $392.5 \mathrm{~mm}$ at Bâlea Lac (The Carpathians). The lowest amounts were recorded in Dobrudja (between 2.8 and $131.8 \mathrm{~mm}$ ), in the south of Moldavia and some areas in Muntenia and Oltenia. Precipitation amounts of over $100 \mathrm{~mm}$ were registered at $21.4 \%$ of the weather stations from Dobrudja, $42.9 \%$ of the stations from Oltenia, $50 \%$ of the stations from Muntenia, and $55 \%$ of the stations from Moldavia. On the other hand, high amounts of precipitation were recorded in The Carpathians (between 94.2 and $392.5 \mathrm{~mm}$ ), followed by Transylvania (between 109.4 and $260.4 \mathrm{~mm}$ ), and Maramureş. 
It must be mentioned that for these regions, over $97 \%$ of the weather stations registered rainfall exceeding $100 \mathrm{~mm}$. In the case of the mountain area, $1 / 3^{\text {rd }}$ of the weather stations recorded more than $200 \mathrm{~mm}$ of precipitation, and $7.7 \%$ of the stations, over $300 \mathrm{~mm}$ (Fig. 4).

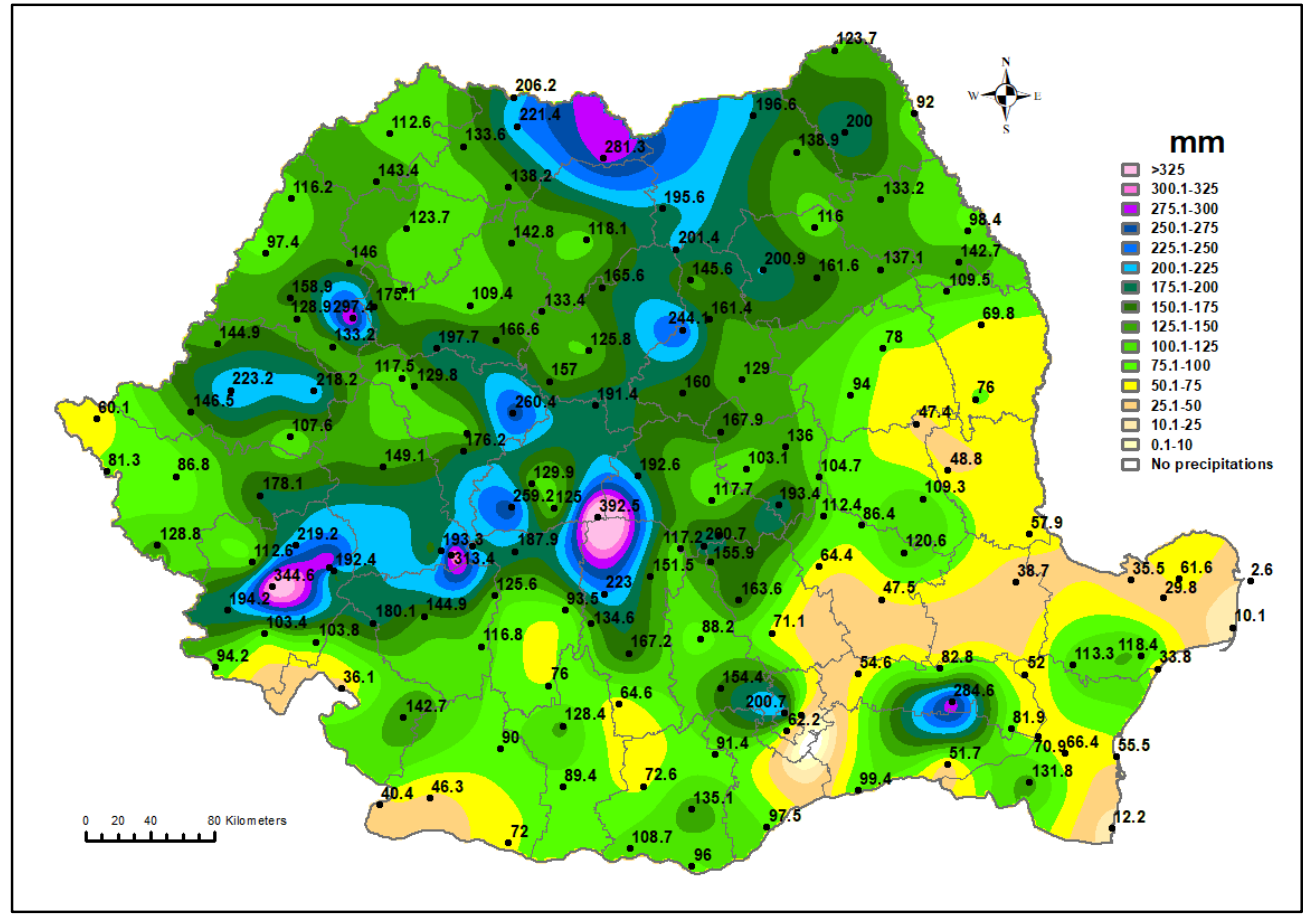

*processed after http://www.meteomanz.com

Fig. 4. Total amount of precipitation in June, 2020, in Romania.

The analyze of the 22 climatological weather stations regarding total amount of precipitation recorded in June, between 1961 and 2020, remarks that only 2 of the stations (Deva and Ocna Şugatag) registered higher amounts of precipitations in 2020.

Most of the weather stations registered higher amounts of precipitation in June, beginning with 1980 (61.5\%), while 22\% of them in 2018 (Table 1).

Regarding the precipitation deviation in June 2020 against 1961-2019 mean, it can be noticed that in case of the climatological weather stations from Moldavia, Dobrudja and some of Muntenia and Oltenia, a negative deviation is observed and it corresponds to the stations situated in lowlands, close to the Danube River; for the climatological weather stations from Banat, Crişana, Maramureş, Transylvania and The Carpathians, a positive deviation is present (Table 1). 
Table 1. Accumulated precipitations in June 2020 (a); absolute maximum accumulated precipitations for 1961-2019 period in June and the recorded year $(\mathrm{mm})$; monthly mean precipitation for 1961-2019 period $(\mathrm{mm})(\mathrm{b})$; precipitation deviation in June 2020 against $1961-$ 2019 mean (\%); absolute maximum number of heavy precipitation days $(R \geq 10 \mathrm{~mm})$ and very heavy precipitation days $(R \geq 20 \mathrm{~mm})$ for different periods of time; and maximum accumulated precipitation in 24, 48 and 72 hours $(\mathrm{mm})$ for different periods, for 22 climatological weather stations of Romania.

\begin{tabular}{|c|c|c|c|c|c|c|c|c|c|c|c|c|c|c|c|}
\hline \multirow[b]{2}{*}{ Region } & \multirow[b]{2}{*}{$\begin{array}{l}\text { Climatological } \\
\text { Weather } \\
\text { Station }\end{array}$} & \multirow[b]{2}{*}{$\begin{array}{c}\text { PP } \\
\text { for } \\
\text { June } \\
2020 \\
(\mathbf{m m}) \\
\text { (a) } \\
\end{array}$} & \multirow[b]{2}{*}{$\begin{array}{c}\text { Abs. max. } \\
\text { PP }(\mathrm{mm}) \\
\text { of June } \\
1961-2019 \\
\text { period/ } \\
\text { recorded } \\
\text { year }\end{array}$} & \multirow{2}{*}{$\begin{array}{c}\text { Mean } \\
\text { PP } \\
(\mathrm{mm}) \\
\text { for } \\
1961- \\
2019 \\
\text { period } \\
\text { (b) }\end{array}$} & \multirow{2}{*}{$\begin{array}{c}\text { PP } \\
\text { deviation } \\
\text { in June } \\
2020 \\
\text { against } \\
1961- \\
2019 \\
\text { mean } \\
(\mathbf{a} / \mathbf{b})^{*} 100 \\
(\%)\end{array}$} & \multicolumn{2}{|c|}{$\begin{array}{c}\text { Abs. max no } \\
\text { of days } \\
\text { R } \geq 10 \mathrm{~mm}\end{array}$} & \multicolumn{2}{|c|}{$\begin{array}{l}\text { Abs. max. no } \\
\text { of days } \\
R \geq 20 \mathrm{~mm}\end{array}$} & \multicolumn{2}{|c|}{$\begin{array}{c}\mathbf{R X 2 4 h} \\
(\mathrm{mm})\end{array}$} & \multicolumn{2}{|c|}{$\begin{array}{c}\text { RX48h } \\
(\mathrm{mm})\end{array}$} & \multicolumn{2}{|c|}{$\begin{array}{l}\text { RX72h } \\
(\mathrm{mm})\end{array}$} \\
\hline & & & & & & $\begin{array}{l}1961- \\
2019 \\
\end{array}$ & 2020 & $\begin{array}{l}1961- \\
2019 \\
\end{array}$ & 2020 & $\begin{array}{l}1961- \\
2019 \\
\end{array}$ & 2020 & $\begin{array}{l}1961- \\
2019 \\
\end{array}$ & 2020 & $\begin{array}{l}1961- \\
2019 \\
\end{array}$ & 2020 \\
\hline \multirow[b]{4}{*}{ East } & Botoşani & 200.0 & $239.2 / 2018$ & 88.2 & 226.7 & 7 & 5 & 3 & 1 & 67.6 & 52.0 & 106.2 & 71.3 & 140.6 & 71.7 \\
\hline & Iași & 98.9 & $291.9 / 1985$ & 89.1 & 111.1 & 7 & 3 & 3 & 1 & 114.2 & 26.7 & 192.8 & 31.4 & 194.4 & 33.9 \\
\hline & Bacău & 78.1 & $184.8 / 2010$ & 88.5 & -88.3 & 7 & 2 & 3 & 1 & 78.8 & 32.9 & 104.5 & 34.3 & 107.2 & 55.4 \\
\hline & Galaţi & 59.0 & $155.5 / 1985$ & 65.2 & -90.4 & 5 & 2 & 2 & 0 & 60.2 & 15.4 & 65.7 & 27.4 & 68.9 & 36.9 \\
\hline \multirow[b]{3}{*}{ South-East } & Tulcea & 22.0 & $160.9 / 1980$ & 54.9 & -40.0 & 6 & 1 & 2 & 0 & 61.8 & 10.3 & 85.6 & 12.4 & 90.4 & 12.4 \\
\hline & Sulina & 1.8 & $117.6 / 2013$ & 28.9 & -6.6 & 4 & 0 & 1 & 0 & 49.4 & 0.7 & 57.8 & 0.7 & 68.0 & 1.0 \\
\hline & Constanţa & 55.0 & $145.0 / 2014$ & 40.5 & 135.8 & 4 & 3 & 1 & 0 & 69.9 & 17.2 & 72.1 & 18.6 & 73.0 & 18.6 \\
\hline \multirow[b]{7}{*}{ South } & Buzău & 47.3 & $178.1 / 1985$ & 81.3 & -58.2 & 6 & 3 & 2 & 0 & 68.8 & 15.7 & 84.0 & 15.9 & 84.0 & 16.8 \\
\hline & București Băneasa & 200.6 & $206.6 / 1969$ & 78.2 & 256.4 & 7 & 4 & 2 & 2 & 70.2 & 85.0 & 86.3 & 88.6 & 86.3 & 88.7 \\
\hline & Călărași & 50.7 & $132.1 / 1978$ & 64.5 & -78.7 & 5 & 2 & 3 & 0 & 58.0 & 14.7 & 70.8 & 25.7 & 104.9 & 28.1 \\
\hline & Roșiorii de Vede & 72.6 & $178.2 / 1983$ & 66.6 & 108.9 & 7 & 3 & 2 & 1 & 65.1 & 21.3 & 74.8 & 29.5 & 84.3 & 33.5 \\
\hline & Râmnicu Vâlcea & 93.1 & $234.2 / 2018$ & 91.0 & 102.3 & 8 & 2 & 3 & 2 & 97.8 & 26.2 & 103.2 & 51.6 & 105.9 & 58.8 \\
\hline & Drobeta Tr.-Severin & 36.1 & $165.0 / 1961$ & 68.0 & -53.1 & 6 & 0 & 2 & 0 & 60.8 & 7.9 & 75.3 & 15.8 & 121.4 & 17.8 \\
\hline & Craiova & 89.8 & $181.2 / 1989$ & 74.2 & 121.1 & 7 & 4 & 2 & 1 & 72.6 & 29.9 & 89.8 & 41.3 & 90.2 & 47.2 \\
\hline \multirow[t]{2}{*}{ West } & Caransebeș & 219.1 & $240.3 / 1969$ & 102.7 & 213.4 & 9 & 6 & 3 & 2 & 91.7 & 78.6 & 100.6 & 103.1 & 100.8 & 105.9 \\
\hline & Arad & 146.1 & $188.1 / 1970$ & 84.3 & 173.3 & 7 & 4 & 1 & 1 & 64.0 & 69.3 & 68.7 & 86.3 & 78.1 & 86.3 \\
\hline \multirow{3}{*}{$\begin{array}{l}\text { North and } \\
\text { Centre }\end{array}$} & Cluj-Napoca & 109.0 & $197.1 / 1998$ & 88.1 & 123.7 & 8 & 4 & 2 & 1 & 63.2 & 26.2 & 80.8 & 30.3 & 82.1 & 34.4 \\
\hline & Deva & 149.1 & $146.0 / 1969$ & 80.6 & 184.8 & 7 & 6 & 2 & 1 & 57.8 & 41.5 & 67.0 & 42.5 & 86.4 & 52.3 \\
\hline & Sibiu & 130.2 & $227.6 / 2018$ & 97.6 & 133.4 & 8 & 4 & 2 & 2 & 70.4 & 36.1 & 88.7 & 59.2 & 104.7 & 62.5 \\
\hline \multirow{3}{*}{$\begin{array}{l}\text { The } \\
\text { Carpathians }\end{array}$} & Ocna Şugatag & 231.2 & $205.9 / 1974$ & 110.9 & 208.5 & 9 & 6 & 3 & 1 & 60.5 & 50.2 & 77.4 & 62.9 & 89.0 & 69.9 \\
\hline & Miercurea Ciuc & 128.6 & $238.0 / 2018$ & 93.8 & 137.2 & 9 & 5 & 3 & 1 & 46.1 & 24.6 & 58.3 & 38.6 & 71.1 & 39.1 \\
\hline & Vârful Omu & 203.0 & $280.8 / 2018$ & 138.4 & 146.7 & 12 & 10 & 4 & 1 & 102.4 & 24.0 & 112.3 & 34.8 & 122.5 & 51.8 \\
\hline
\end{tabular}

*processed after http://data.gov.ro/dataset and http://www.meteomanz.com 
In order to determine if precipitations recorded in June 2020 were higher than those from 1961-2019 period, 5 precipitation indices were analyzed. For June, 2020, for the 22 climatological weather stations, the number of heavy precipitation days was between 0 and 5 days in the lowland regions, between 4 and 6 days in Banat, Crişana, Transylvania, and between 5 and 10 days in the Carpathians, but it did not exceed the absolute maximum number registered in 1961-2019 period (Table 1). In the case of very heavy precipitation days, in 2020, climatological weather stations situated in lowlands did not register more than 2 days, while the mountain area had between 1 and 3 days (Table 1).

It can be observed that in 2020, in Banat, Crişana, Transylvania and the Carpathians region, the number of very heavy precipitation days equaled the absolute maximum number of the days registered between 1961 and 2019, in only 4 cases (Table 1).

Maximum accumulated precipitations in 24, 48 and 72 hours in June, 2020 exceed the same indices for 1961-2019 period only at two climatological weather stations, in the case of maximum 24 hours accumulated precipitations (Bucureşti Băneasa and Arad), respectively at three weather stations, for maximum 48 and 72 hours accumulated precipitations (Bucureşti Băneasa, Caransebeş and Arad), as data from Table 1 shows.

As convective precipitations present an uneven spatial distribution, the only 22 climatological weather stations were not enough to emphasize the extent and the magnitude of the phenomena to the entire country.

For a better understanding of spatial distribution of precipitations recorded in June 2020, in Romania, additional analyze of heavy and very heavy precipitation days was made. In the case of heavy precipitation days, at least 1 day or more was registered at all the weather stations from the country, except for $28 \%$ of those from Dobrudja and $2 \%$ of those from Muntenia and Oltenia; at least 3 days or more of heavy precipitation days were registered at more than $95 \%$ of the weather stations from Banat and Crişana, Maramureş and Transylvania, and the Carpathians region, while in Moldavia, Muntenia and Oltenia and Dobrudja, less than $70 \%$ of the stations exceeded that value (Fig. 5).

In the case of very heavy precipitation days, the distribution revealed mostly the same structure: the higher the number of very heavy precipitation days were, the less weather stations reaching or exceeding that number was. Another feature is that the percent of the weather stations from the Carpathians, Maramureş and Transylvania, and Banat and Crişana that registered very heavy precipitation days, was higher than those from the other regions (Fig. 5). The differences between regions for both heavy and very heavy precipitations days were determined by the patterns of synoptic conditions and the mesoscale system's tracks, combined with local conditions: humidity in the lower troposphere, rise of the daily temperatures, the presence of convergence lines.

Regarding the number of cases of different consecutive heavy precipitation days, it can be observed that were not exceeded 8 days, while, in the case of consecutive very heavy precipitation days, it was up to 5 days (Fig. 6). 


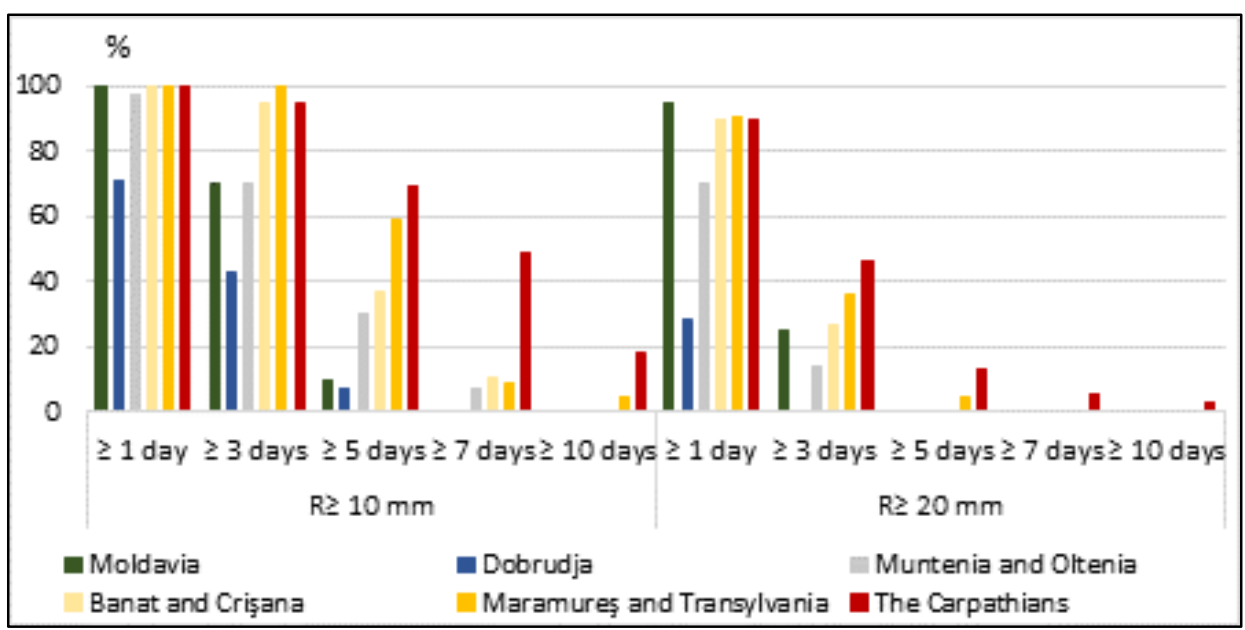

*processed after http://www.meteomanz.com

Fig. 5. Frequency of heavy precipitation days $(R \geq 10 \mathrm{~mm})$ and very heavy precipitation days $(R \geq 20 \mathrm{~mm})$, according to their occurrence in June, 2020.

Two consecutive heavy precipitation days were recorded in all regions, but the highest number of cases were in the Carpathians, in Muntenia and Oltenia, and in Maramureş and Transylvania; 3 consecutive days were recorded mostly in the same regions while more than 4 consecutive days were registered only in the mountain area (Fig. 6). At least 2 consecutive days of very heavy precipitations were registered almost in all regions of Romania (except Dobrudja), while 3 consecutive days or more, mostly in the mountain area (Fig. 6).

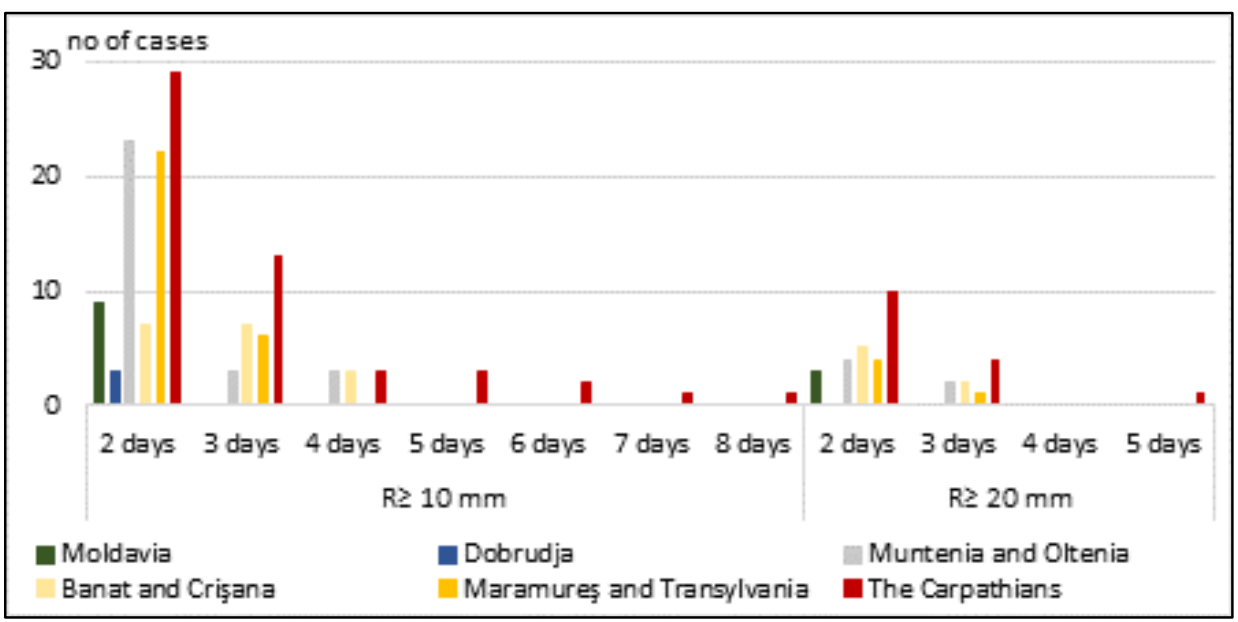

*processed after http://www.meteomanz.com

Fig. 6. Number of cases of consecutive heavy precipitation days $(R \geq 10 \mathrm{~mm})$ and very heavy precipitation days $(R \geq 20 \mathrm{~mm})$, recorded in June, 2020. 
It can be concluded that as the number of consecutive days grows, the less cases are recorded and the phenomena is more frequent in the Carpathians, in Banat and Crişana, and in Maramureş and Transylvania, as the local conditions contributed to the development of the convective systems.

\subsection{Mesoscale conditions}

As presented in the synoptic conditions, beginning with the $9^{\text {th }}$ of June, Romania was under the influence of a SLP under $1010 \mathrm{hPa}$, and a weak atmospheric pressure gradient, while, in the middle troposphere, a geopotential trough was present, within a series of rotating cut-off lows. The southern air circulation assured a moist and warm air advection generating favorable conditions for convective storms and excessive precipitations especially on the lee slopes of The Carpathians.

\section{June, $9^{\text {th }}$ and $10^{\text {th }}, 2020$}

On the $9^{\text {th }}$ and $10^{\text {th }}$ of June, as the maximum temperatures registered were between 25 and $30^{\circ} \mathrm{C}$ in the north-west half of the country, and between 30 and $34^{\circ}$ $\mathrm{C}$ in the south-east part of it, and the presence of some convergence lines in the lower troposphere, generated a medium atmospheric instability. The observed CAPE was of $700-1000 \mathrm{~J} / \mathrm{kg}$, while in Banat and some parts of Oltenia and Muntenia reached $1500-2000 \mathrm{~J} / \mathrm{kg}$, and LI was of -4 to -2 (Fig. 7). As the vertical shear in the $0-3 \mathrm{~km}$ was weak (less than $10 \mathrm{~m} / \mathrm{s}$ ), as well as the atmospheric pressure gradient, a series of pulsating storms developed, moving northward, but only a few generated torrential rains; the maximum amount of precipitation recorded was up to $49 \mathrm{~mm}$ in the Southern Carpathians (Fig. 8).

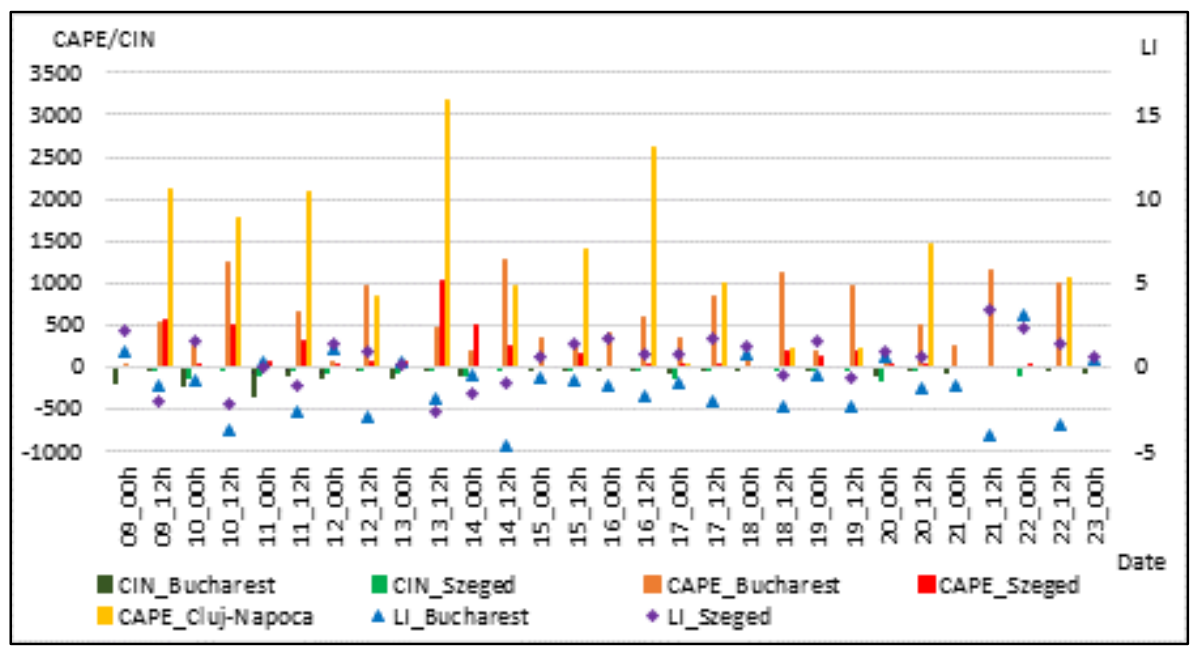

*data processed after http://weather.uwyo.edu/upperair/sounding.html for Bucharest and Szeged, and after https://www.tropicaltidbits.com/ for Cluj-Napoca).

$* *$ forecasted data for Cluj-Napoca).

Fig. 7. CAPE, CIN and LI between 9 and 23 of June, 2020, for 3 atmospheric sounding sites: Bucharest, Szeged and Cluj-Napoca (CAPE/CIN - J/Kg). 
Beginning with $11^{\text {th }}$ of June, weather conditions in Romania was under the influence of a retrograde cyclone situated in the eastern and south-eastern part of the country, while, in the middle troposphere, a cut-off low was present. On $11^{\text {th }}$ and $12^{\text {th }}$ of June, high values of CAPE of over 1500-2000 J/Kg were observed over the East region, while on the $13^{\text {th }}$ of June, CAPE over $2000 \mathrm{~J} / \mathrm{Kg}$ was present over Maramureş and Transylvania (Fig. 9);
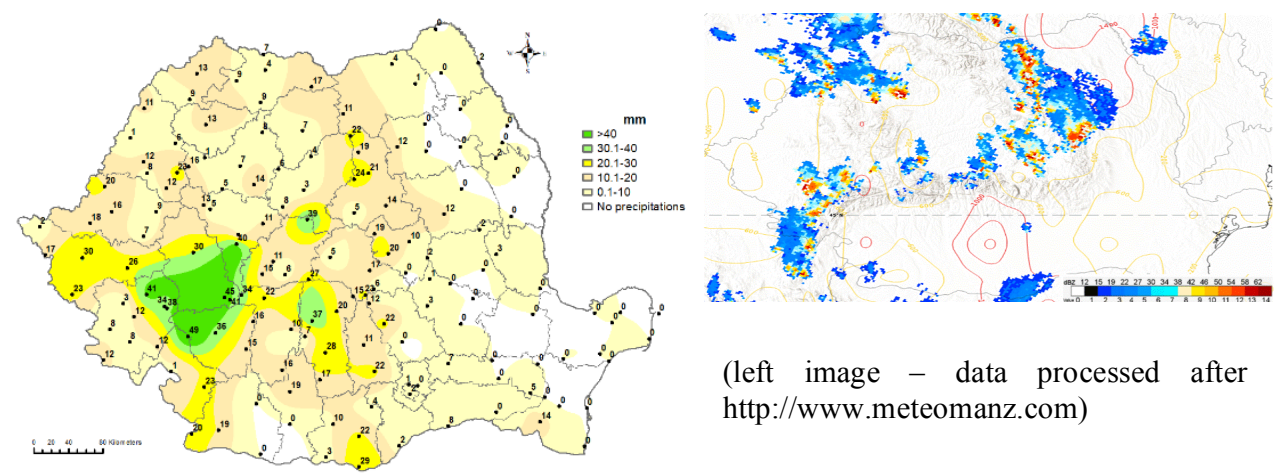

Fig. 8. Amount of precipitation registered on the $9^{\text {th }}$ and $10^{\text {th }}$ of June 2020, in Romania (left); radar reflectivity (dBZ) and CAPE (J/Kg), on 10.06.2020, 12 UTC (right).

\section{June, 11 to 13,2020}

LI registered negative values, up to -3 as data from Figure 7 shows. Another ingredient of convective storms registered in that period was diurnal heating, as maximum temperatures on $11^{\text {th }}$ were over $30^{\circ} \mathrm{C}$ in Moldavia while on the $12^{\text {th }}$ and $13^{\text {th }}$ the temperatures were between 26 and $32^{\circ} \mathrm{C}$. As a result, a series of convective storms developed over Moldavia and migrate over the Eastern Carpathians, Transylvania and the Western Carpathians, driven by the general circulation in the lower and medium troposphere.
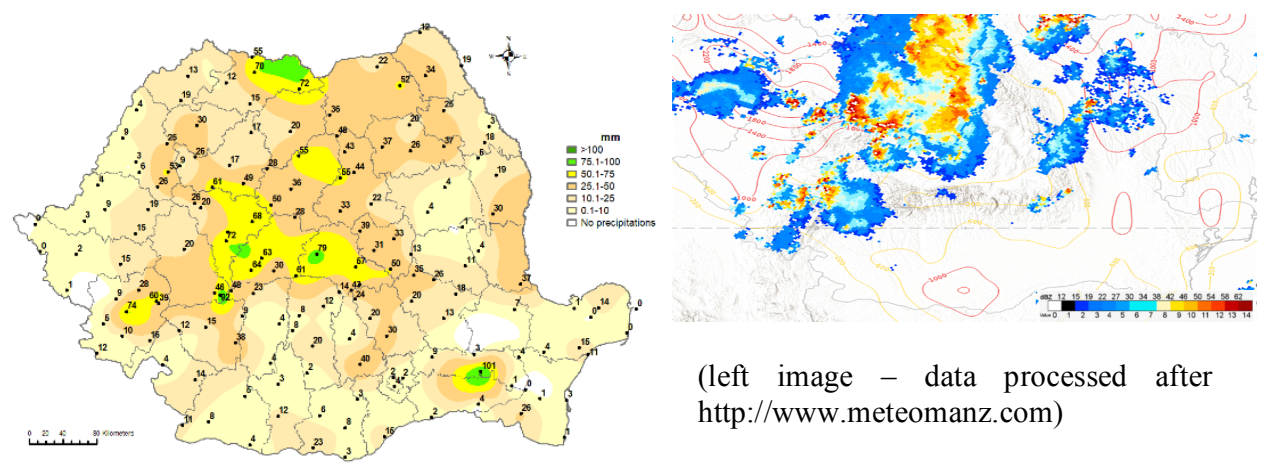

Fig. 9. Amount of precipitation registered from $11^{\text {th }}$ to $13^{\text {th }}$ of June 2020, in Romania (left); radar reflectivity (dBZ) and CAPE (J/Kg), on 13.06.2020, 18 UTC (right). 


\section{June, $14^{\text {th }}$ and $15^{\text {th }}, 2020$}

The storms organization was different from the $9^{\text {th }}$ and $10^{\text {th }}$ period, as vertical shear in the $0-3 \mathrm{~km}$ layer was higher $(15-20 \mathrm{~m} / \mathrm{s})$, generating long lasting storms and higher amounts of precipitation, as can be seen in Figure 9. High amounts of precipitation accumulated in the north-east part of Moldavia, eastern and southern Carpathians, in Maramureş and Transylvania and scattered, in Muntenia (on the $13^{\text {th }}$ of June, at 16 UTC, Slobozia weather station registered, $85 \mathrm{~mm}$ of precipitation in one hour or less).

For this period, a retrograde cyclone affected mostly the Southern and the SouthEastern regions of the country while a cut-off low was situated over the Black Sea (Fig. 10). Maximum temperatures of over $24^{\circ} \mathrm{C}$ registered in Muntenia and Oltenia, high humidity in the lower troposphere, as well as humidity advection over the Black Sea, represented ingredients for convective storms.

As a result, CAPE of 1000-1300 J/kg was registered in Oltenia, Transylvania and parts of Muntenia, while in Banat was up to $2000 \mathrm{~J} / \mathrm{Kg}$, and LI reached up to -5 in Muntenia (Fig. 7).

Most of the storms developed in the period mentioned above were short lived storms, as vertical shear was low. High amounts of precipitation were recorded in the western and central Muntenia, the western Oltenia, central part of the Southern Carpathians, and to some isolated weather stations in Banat and Crişana (Fig. 10).
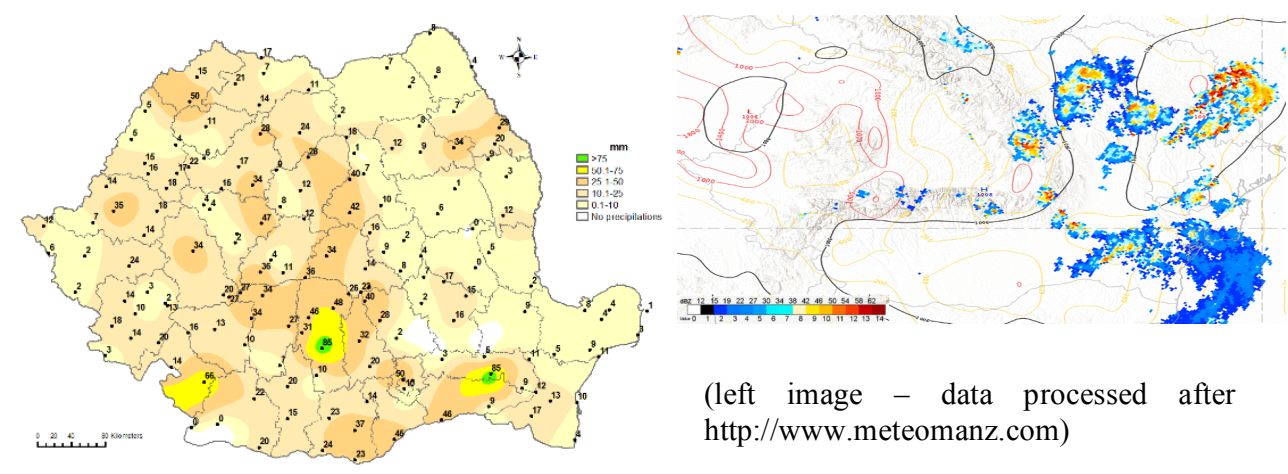

Fig. 10. Amount of precipitation registered on the $14^{\text {th }}$ and $15^{\text {th }}$ of June 2020, in Romania (left); radar reflectivity (dBZ), CAPE (J/Kg), and SLP (hPa) on 14.06.2020, 09 UTC (right).

\section{June, 16 to 18,2020}

A major synoptic characteristic of June 16th to 18 th was the presence at the SLP of a depression in the west-north-western part of Romania while in the medium troposphere, a cut-off low situated in the same position where the last one has been recorded (Fig. 11). 
The maximum temperatures registered on the $16^{\text {th }}$ of June over the western half of the country were between 23 and $27^{\circ} \mathrm{C}$ and on the $17^{\text {th }}$ of June, dropped to 18 to $22^{\circ} \mathrm{C}$, due to high cloud cover. On the $18^{\text {th }}$ of June, the maximum temperatures recorded in the region mentioned above rose to 20 to $25^{\circ} \mathrm{C}$. On these circumstances, CAPE values of only $800-1000 \mathrm{~J} / \mathrm{Kg}$ were recorded, but LI values were negative, especially in the South region (Fig. 7).

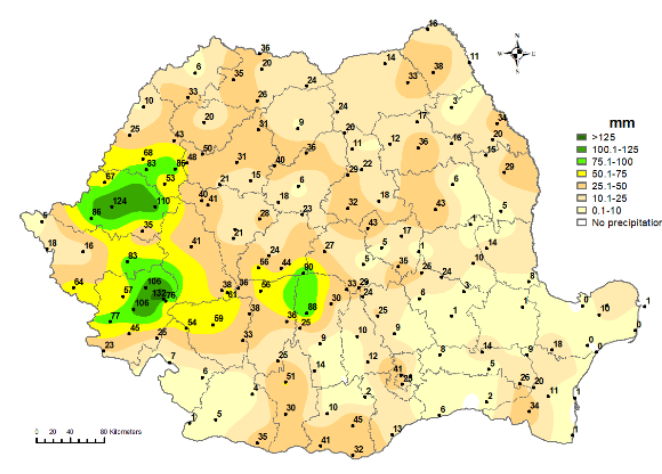

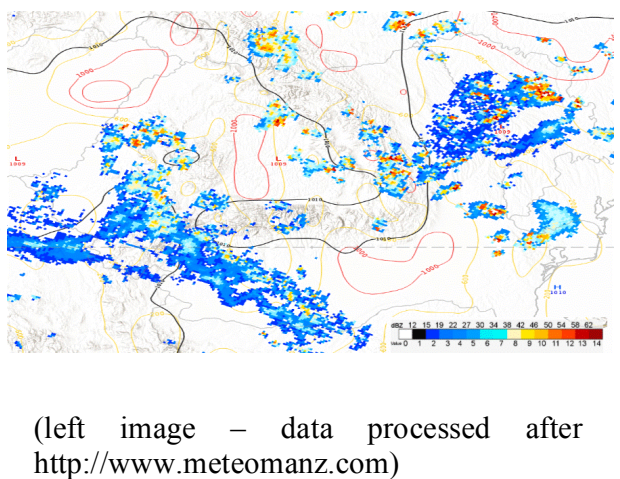

http://www.meteomanz.com)

Fig. 11. Amount of precipitation registered from $16^{\text {th }}$ to $18^{\text {th }}$ of June 2020, in Romania (left); radar reflectivity (dBZ), CAPE (J/Kg), and SLP (hPa) on 16.06.2020, 09 UTC (right).

For the entire period, a weak wind shear in the lower 0-3 km layer was observed but the presence of the convergence line between the cut-off low and the depression at the surface played an important role in the genesis and evolution of the convective storms.

For 3 days, high amounts of precipitations were recorded in Banat, Crişana and Western and Southern Carpathians, as in the other regions, precipitations were recorded mostly on the $16^{\text {th }}$ and/or on the $18^{\text {th }}$ of June, as a result of the surface heating. The highest amounts of precipitations were recorded in the south of Crişana, the east of Banat and Western Carpathians, as the Figure 11 shows.

\section{June, $20^{\text {th }}, 2020$}

The main synoptic feature of the day was the presence of a depression in the eastsouth-east of Moldavia, and a north-eastern air circulation in the lower troposphere. In the middle troposphere, Romania was under the influence of a cut-off low that mowed and extended from the west part of the country, to the east.

Low to medium values of CAPE ranging from 500 to $1500 \mathrm{~J} / \mathrm{Kg}$ (Fig. 7) and weak low level wind shear generated favorable conditions for pulsating storms that developed in the north part of Moldavia and moved southward.

The maximum temperatures recorded in Moldavia were between 23 and $29^{\circ} \mathrm{C}$, generating enough energy for the storms to develop. As the map of precipitations from $20^{\text {th }}$ of June shows (fig. 12, left), only the northern part of the mentioned region 
registered high amounts of precipitations, while in the other regions of the country, intensive rainfalls were rather isolated.

June, $22^{\text {nd }}, 2020$

On the $22^{\text {nd }}$ of June 2020, a depression was present in the eastern and northeastern parts of Romania, as in the middle troposphere, geopotential cut-off low weakened during the night.
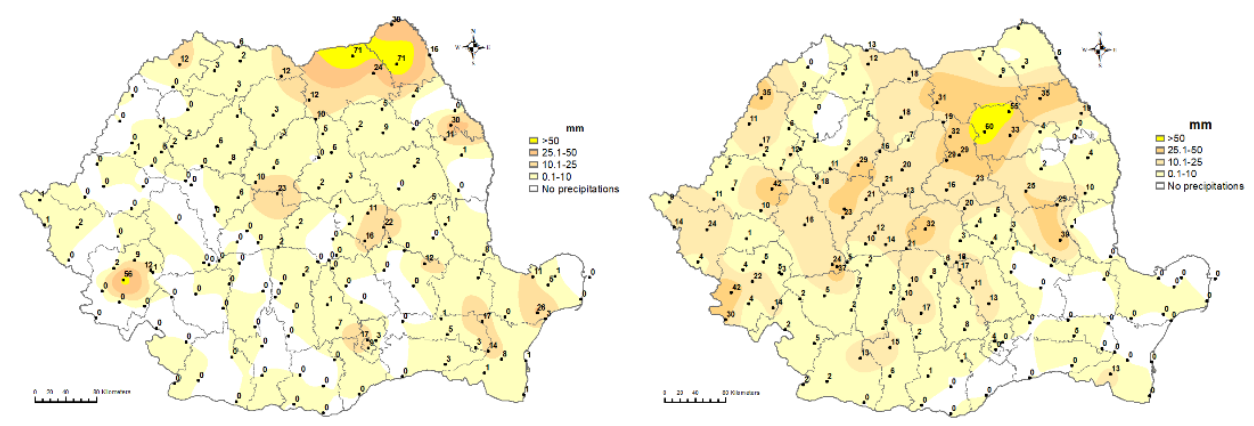

*processed after http://www.meteomanz.com

Fig. 12. Amount of precipitation registered on the $20^{\text {th }}$ of June, 2020 (left) and $22^{\text {nd }}$ of June, 2020 (right), in Romania.

As a result, in the lower troposphere, the air circulation over the Moldavia changed, from east, to north-east and finally, north. The diurnal heating generated maximum temperatures between 23 and $29^{\circ} \mathrm{C}$, and values of over $25^{\circ} \mathrm{C}$ were registered in Moldavia, Dobrudja, Muntenia and Oltenia. CAPE reached values of $1000-1500 \mathrm{~J} / \mathrm{Kg}$ (Fig. 7) and wind shear in the $0-3 \mathrm{~km}$ layer was ranging between 5 to $10 \mathrm{~m} / \mathrm{s}$.

As a result, pulsating storms developed in different parts of the country but in Moldavia the presence of a convective line determined a convective system that moved southward, generating precipitations in the western part of the region (Fig. 12 , right).

\section{CONCLUSIONS}

The study of precipitations registered in June 2020 in Romania revealed differences regarding the synoptic and mesoscale conditions that played an important role in the genesis of convective storms, as well as differences between the different regions of the country.

The study of 5 precipitation indices for 22 climatological weather stations led to the conclusion that precipitations recorded in June did not exceeded the absolute maximum precipitations for the month, except only for two stations. More than that, the number of heavy and very heavy precipitation days recorded 
in June 2020 were not higher than those from 1961-2019 period, and maximum precipitations recorded in 24, 48 and $72 \mathrm{hrs}$. were higher only in the case of 2 and 3 weather stations in June, 2020.

The extended analyze of number of heavy and very heavy precipitation days for all 156 weather stations from Romania, for June 2020, showed that higher number of heavy precipitation days and very heavy precipitation days were registered to a higher number of weather stations from The Carpathians, in Maramureş and Transylvania, and in Banat and Crişana; weather stations from Dobrudja, and from Muntenia and Oltenia had a smaller number of heavy and very heavy precipitation days and were registered by fewer weather stations.

Synoptic conditions from $9^{\text {th }}$ to $22^{\text {nd }}$ of June 2020 generating high amounts of precipitations were influenced by the low values of SLP (between 1000 and 1010 $\mathrm{hPa}$ ), the weak pressure gradient and/or the presence of an atmospheric depression. In the middle troposphere, an atmospheric trough or a cut-off low was present, but the position of the two pressure structures over the territory of Romania had a great influence over the movement of the storms and spatial distribution of precipitations.

Mesoscale conditions, as an important feature in generating convective storms, were characterized by low and medium values of CAPE (rarely over $2000 \mathrm{~J} / \mathrm{Kg}$ ), mostly negative values of LI (no more than -5), low or medium wind shear in the lower 0-3 km layer (mostly up to $10 \mathrm{~m} / \mathrm{s}$ ), and an instable environment generated by high humidity near the surface and daily maximum temperatures that not exceeded $33^{\circ} \mathrm{C}$. As a result, most of the storm were pulsating storms and high amounts of precipitations from different periods of June 2020 were determined by accumulation, rather than being a singular event.

Numerous showers that took place and Romania led to a rapid increase in the river's water flow. Consequently, flooding events took place, prompting evacuations. For example, 3 people died (one in Bihor County, one in Suceava County, one in Vaslui County) due to multiple flooding events that took place between June, 23-26. Approximately 152 people were evacuated, while 387 houses, seven electricity poles, and 16 road sections were damaged (https://reliefweb.int/report/romania/romania-floods-igsu-meteoromania-floodlistmedia-echo-daily-flash-24-june-2020).

The maximum level alert (red, 3/3) was issued for rivers in Caraş Severin, Neamţ, Hunedoara, Botoşani and Maramureş counties during June 2020, where evacuations, minor road and crop damage and building floodings took place, too.

Other minor floodings, rather than the one mentioned above, happened widely in Romania during June 2020 but without notable bad consequences (https://reliefweb.int/report/romania/romania-floods-igsu-meteoromania-floodlistmedia-echo-daily-flash-24-june-2020)

\section{REFERENCES}

1. Alexander L.V., Zhang X., Peterson T.C. (2006), Global observed changes in daily climate extremes of temperature and precipitation. Journal of Geophysical Research, 111, 1-22, DOI: 10.1029/2005JD006290. 
2. Băcescu A., Sfîrlează F. Colan M., Burada C., (2012/2013), Inundaţiile din 1 iunie din Municipiul RM. Vâlcea, Revista Ştiinţifică a Administraţiei Naţionale de Meteorologie, ISSN 2069 - 878X, Bucureşti, 3-8.

3. Blaga I., 2016, Furtuni supercelulare în nord vestul României - 17/18 iunie 2016, Revista Ştiinţifică a Administraţiei Naţionale de Meteorologie, ISSN 2069 - 878X, Bucureşti, 3-12.

4. Covaci I.E., Dragomir M., (2016), Inundațiile din Moldova de la începutul lunii iunie 2016, Revista Ştiintifică a Administraţiei Naţionale de Meteorologie, ISSN 2069 878X, Bucureşti, 14-25.

5. Dragotă C.S., (2006), Precipitațiile excedentare în România. Editura Academiei Române. 21-36.

6. Draxler R.R, Rolph G.D (2012), HYSPLIT (HYbrid Single-Particle Lagrangian Integrated Trajectory) Model access via NOAA ARL READY. NOAA Air Resources Laboratory, Silver Spring, http://ready.arl.noaa.gov/HYSPLIT.php

7. Klein Tank A. M. G., Können G. P. (2003), Trends in Indices of Daily Temperature and Precipitation Extremes in Europe, 1946-1999, Journalof Climate, $\quad 16, \quad 3665-3680$. DOI: https://doi.org/10.1175/15200442(2003)016<3665:TIIODT $>2.0 . \mathrm{CO} ; 2$

8. Ligda, M. G. H., (1951), Radar storm observations. In Compendium of Meteorology, American Meteorological Society, Boston, 1265-1282.

9. Pasat C., Vasilică M., (2016), Caracteristici ale sistemelor mezoscalare convective ce au afectat Moldova în intervalul 18-20 iunie 2016, Revista Ştiinţifică a Administraţiei Naţionale de Meteorologie, ISSN 2069 - 878X, Bucureşti, 58-66.

10. Polifronie E.M., (2014), Luna iulie 2014 - A patra cea mai ploioasă din ultimii 50 de ani. Revista Ştiinţifică a Administraţiei Nationale de Meteorologie, ISSN 2069 878X, Bucureşti, 43-58.

11. Sandu I., Pescaru V.I., Poiana I., (2008), Clima Romaniei, Editura Academiei Romane, Bucharest.

12. Stăncescu M., Reckerth U., (2016), Fenomenele meteorologice severe din 19 iunie 2016, localitatea Cuci, judeţul Mureş - analiză postoperaţională, Revista Ştiinţifică a Administraţiei Naţionale de Meteorologie, ISSN 2069 - 878X, Bucureşti, 93-110.

13. WMO (2018), Guide to Climatological Practices. [online], URL: https://library.wmo.int/doc_num.php?explnum_id=5541. Accessed on 02.12.2020.

14. ${ }^{* * *}$ IPCC, 2018: Global Warming of $1.5^{\circ} \overline{\mathrm{C}}$. An IPCC Special Report on the impacts of global warming of $1.5^{\circ} \mathrm{C}$ above pre-industrial levels and related global greenhouse gas emission pathways, in the context of strengthening the global response to the threat of climate change, sustainable development, and efforts to eradicate poverty [Masson-Delmotte, V., P. Zhai, H.-O. Pörtner, D. Roberts, J. Skea, P.R. Shukla, A. Pirani, W. Moufouma-Okia, C. Péan, R. Pidcock, S. Connors, J.B.R. Matthews, Y. Chen, X. Zhou, M.I. Gomis, E. Lonnoy, T. Maycock, M. Tignor, and T. Waterfield (eds.)].

15. http://data.gov.ro/dataset (accessed on 15.10.2020)

16. https://www.ecad.eu/documents/ETCCDMIndicesComparison.pdf (accessed on 10.10.2020)

17. https://www.estofex.org/modelmaps/browse_gfs.php (accessed on 03.01.2021)

18. http://eumetrain.org/ePort_MapViewer/index.html (accessed on 10.02.2021)

19. https://glossary.ametsoc.org/wiki/Cyclonic_scale (accessed on 22.02.2021)

20. http://www.inhga.ro/warnings (accessed on 25.02.2021)

21. https://meteologix.com/ro/reanalysis (accessed on 27.02.2021) 
22. http://www.meteomanz.com (accessed on 11.10.2020)

23. https://reliefweb.int/report/romania/romania-floods-igsu-meteoromania-floodlistmedia-echo-daily-flash-24-june-2020 (accessed on 24.02.2021)

24. http://weather.uwyo.edu/upperair/sounding.html (accessed on 03.11.2020)

25. http://www1.wetter3.de/archiv (accessed on 17.02.2021) 